\title{
Expansion and Disparities in Higher Education in India: The Neo-Liberal Impact
}

\section{Jaspreet Kaur}

Department of Education, Panjab University, Chandigarh, India

Corresponding author: jaspreetkaur.jk19@gmail.com

Received: 21-09-2021 Revised: 17-11-2021 Accepted: 10-12-2021

\begin{abstract}
In this era of technological advancement higher education has a very important role to play. Higher education in India is going through an important transition. After the adoption of new economic policy in 1991 there are many changes happen in the political and economic set up of the country which has its impact on the education sector also. This post reform period has put the state back and pushes the private sector in the field of education especially in the higher education. There is huge expansion of higher education institutions since last two decades which are mainly due to private institutions and deals with the professional and technical education. The high cost of education in these private educational institutions is a major concern to the access and equity in higher education. This leads to many disparities like regional disparities, gender disparities and inter-state disparities to access higher education. This paper is based on the secondary data collected from the All India Survey of Higher Education Report. The first part of the paper deals with the expansion of higher education in terms of institutions and enrollment which highlights how the privatization and commercialization have lead to the expansion of higher education institutions. The second part of the paper deals with the impact of privatization on higher education which highlights how this huge expansion leads to exclusion due to high cost of education and also discuss the threats of privatization in higher education in terms of various disparities related with region, gender etc.
\end{abstract}

Keywords: Higher Education, Neo-Liberalism, Expansion, Exclusion, Disparities

Education plays significant role for the social and economic development of the society. Access to education is critical to access the opportunities that accompany economic growth. In this era of technological advancement higher education has a very important role to play. In India, we have second largest higher education system in the world both in terms of number of institutions and number of enrolment of students. Higher education in India is going through an important transition. The major trend in the development of higher education shows that the state tend to slowly withdraw from the responsibility of higher education by adopting the policy of non- intervention and by giving free hand to the private sector in higher education to grow. Though, in recent decades, the higher education system in our country has witnessed a tremendous growth in many aspects such as growth of institutions, in terms of enrolment of the students, teacher- student ratio, etc., but this rapid expansion of the higher education system as a whole has brought several pertinent issues related to access, equity, efficiency and excellence in higher education in the country. This paper has made attempt to discuss the expansion of higher education both in terms of number of institutions and enrollment and also highlighted the disparities prevalent in various

\footnotetext{
How to cite this article: Kaur, J. (2021). Expansion and Disparities in Higher Education in India: The Neo-Liberal Impact. Educational Quest: An Int. J. Edu. Appl. Soc. Sci., 12(03): 179-184.
} 
groups to access the higher education in India. This paper is based on the secondary data collected from the All India Survey of Higher Education Report. First part of the paper deals with the expansion of higher education that highlights how the privatization and commercialization have lead to the expansion of higher education institutions. The second part of the paper highlights how this huge expansion leads to exclusion due to high cost of education. And discuss the threats of privatization in higher education in terms of various disparities related with region, gender, caste etc.

\section{Neo-Liberalism and Higher Education in India}

After independence, India adopted the mixed economy model in which the major means of production were in the hands of state and the state adopted the welfare approach for the social and economic development of the country which includes the education sector also. In the last decade of the $20^{\text {th }}$ century, the entire world has witnessed a paradigm shift in almost all sectors of economy. With the adoption of neoliberal economic reform programmes in 1990s and subsequent globalization of the Indian economy, there has been a redefining of the role of the Indian state. The new economic reform policies which include stabilization and structural adjustment through drastic cut in public expenditure have led the government to retreat from financially supporting education in general and higher education in particular. Adjustment policies directly and indirectly contribute to restoration of the market mechanism in general and privatization of education in particulardirectly, as adjustment policies specifically include privatization and marketization, and indirectly, through a reduction in government subsidies (Tilak, 2018). In the era of neo-liberalism, higher education is being conceptualized in economic terms of supporting the growing market economy by preparing an educated and skilled workforce and making the economy competitive in the global economy. Such a conception of higher education has been accompanied with defining of higher education as a private good or a non-merit good in the policy discourse. Such a conceptualization of higher education has built a rationale for opening up this sector for large scale privatization and commercialization (Singh, 2014). In the name of curtailing the unwanted subsidies to reduce fiscal deficits, the government has progressively reduced expenditure on education. The neo-liberal mantra of the market and the privatization has led the government to slowly change its view on education from public good to a tradable service (Patnaik, 2007). Kapur and Mehta (2004) argued that even though the state negates the de jure privatization in education sector but de facto privatization is there on massive scale. And this is not resulted from the changing ideological commitment of the state but due to the breakdown of the state system and an exit of Indian elites from the public institutions to private sectors both within the country and in abroad. Consequently, during the last decade, most of the expansion in terms of number of institutions took place in the private sector. Tilak (2014) have seen this policy shift from the policy of welfare in higher education to market based approach to higher education in the two important phases. First, in the early phase of 1990's though the central and state government was not in favour of private education but the neo-liberal forces compelled the state to adopt policies of privatization as privatization is an important component of neoliberal policies associated with World Bank and IMF. After that, in the second phase the state changed its perception towards private sector in education and considers it as a good means of more access, quality and equity in higher education.

Most of the expansion before the mid 1990's was in public higher education system, the post mid 1990's expansion of higher education was mainly due to the private/self financing/ unaided/ for profit higher education. Rao (2017) discussed the two phases of privatization between the period of 1995 to 2007-08 and in 2008-09. The period of 1995 to 2007-08 marked the process of withdrawal of the state from provisioning of public higher education and the period after 2008-09 marked a clear engagement of the state in pushing privatization hard by even pumping the name of vouchers and fee reimbursement schemes. In the post2000 period, the expansion of higher education has been mostly in the private sector and in professional education according to the demand of this globalised employment market. The revival and expansion of higher education sector in India 
was accompanied by fast growth of private higher education institutions. The period of 1990-91 to 2012-13 experienced a very high growth rate in terms of enrolment, proliferation of capitation fee colleges, deemed to be universities in the private sector and the emergence of private universities through state legislation. The overall growth increased from 4.0 percent during 1970-90 to 9.1 percent during 1990-2013. The growth rate was still higher at 11.7 percent during the more recent period of 2001-02 to 2012-13. The GER increased from 5.9 to 21.1 percent during the period of 19902012 (Varghese, 2015). Clearly, this expansion has posed certain questions. Does mere quantitative expansion bridge the gap of access and equity for various sections of the society?

\section{Expansion in Higher Education}

In India, we have many higher education institutions central public universities, state universities, institutions deemed to be university and private universities which provide education in different fields like general education, professional and technical education. There is huge expansion of higher education institutions since last two decades which are mainly due to private institutions and deals with the professional and technical education. The changing role of state and rise in market forces all contributed to the emergence of a wide variety of new providers of higher education particularly in those courses which give more monetary profits .As a result, during the past few decades education institutions providing professional education such as medical /technical universities, Institutes/colleges, and polytechnics have come into existence. In the recent past, the growth trends in higher education seem to have found favour with those courses of study that have high economic payoffs (Kaur, 2014). The period of last two decades is the period of huge expansion in higher education both in terms of institutions and enrolment. There were just 185 universities in 1990-91, their number increased to 903 by $2017-18$ and there were 6627 colleges recognized by UGC in 1990-91 with enrolment of 5.9 percent and the number of colleges increased to 38061 by $2017-18$ with the enrolment of 25.8 percent.

\section{Expansion in terms of number of Higher Education Institutions}

Table 1: Number of Universities in India

\begin{tabular}{lll}
\hline Institutions & Number & Percentage \\
\hline Central universities & 46 & 5.09 \\
State public universities & 367 & 40.64 \\
State private universities & 263 & 29.13 \\
$\begin{array}{l}\text { Institutions Deemed to be } \\
\text { university }\end{array}$ & 123 & 13.62 \\
$\begin{array}{l}\text { Institutions established under state } \\
\text { legal act }\end{array}$ & \\
Institutions of national importance & 101 & 0.33 \\
Total & $\mathbf{9 0 3}$ & $\mathbf{1 0 0}$ \\
\hline
\end{tabular}

Source: AISHE (2017-18).

Table 2: Number of Government and Private Colleges

\begin{tabular}{lll}
\hline Institutions & Number & Percentage \\
\hline Government Colleges & 8358 & 22 \\
Private Aided Colleges & 5083 & 13 \\
Private Unaided Colleges & 24620 & 65 \\
\hline Total & 38061 & 100 \\
\hline
\end{tabular}

Source: AISHE (2017-18).

The number of higher education institutions is increasing at very fast pace in our country. There is 46 central universities, 367 state public universities, 263 state private universities, 123 institution deemed to be university and 101 institutions of national importance are there in our higher education sector with high number of colleges 38061. Majority of the Colleges (78 percent), are privately managed, out of which 64.7 percent are private unaided and 13.3 percent are private aided and the remaining 22 percent are Government Colleges in the Country. There are wide variations among states in number of private colleges. Among the major States, in each of Andhra Pradesh and Telengana States, Privateunaided colleges constitutes about 82 percent, followed by Tamil Nadu 76.2 percent and Assam has 12.0 percent Private-unaided colleges. Majority of colleges are smaller in terms of enrolment as 18.5 percent of the Colleges are having enrolment less than 100 and 46.7 percent of the colleges have student strength of 100 to 500 which means 65.2 percent of the colleges have enrolled less than 500 
students. Only 3.6 percent Colleges have enrolment more than 3000 students. There are 33.8 percent Colleges, which run only single programme, out of which 83 percent are privately managed. Among these, 55.1 percent colleges run B.Ed. Courses only. And Stand Alone Institutions are mainly run by Private sector (75.47 percent); Private unaided 66.04 percent and Private aided 9.43 percent. Only 24.53 percent Institutions are in Government sector and 55.9 percent Institutions are located in Rural Area (AISHE 2017-18).

\section{Expansion in terms of GER}

With the rising cost of higher education and shift from public to private entities in higher education, the issues of access and inclusiveness predominantly came into force. Accessibility to higher education is measured in terms of gross enrolment ratio (GER) which is the ratio of persons enrolled in higher education institutions to total population of the persons in the age group of 18-23 years.

Table 3: GER in Higher Education by States in India

\begin{tabular}{llll}
\hline State/UT & GER & State & GER \\
\hline A\&N & 21.8 & Lakshadweep & 7.6 \\
Andhra Pradesh & 30.9 & Madhya Pradesh & 21.2 \\
Arunachal Pradesh & 29.7 & Maharashtra & 31.1 \\
Assam & 18.2 & Manipur & 31.8 \\
Bihar & 13.00 & Meghalaya & 24.7 \\
Chandigarh & 56.4 & Mizoram & 22.9 \\
Chhattisgarh & 18.4 & Nagaland & 17.8 \\
Dadra \& Nagar & 9.1 & Odisha & 22.00 \\
Haveli & & & \\
Daman \& Diu & 5.2 & Pondicherry & 45.4 \\
Delhi & 46.3 & Punjab & 30.3 \\
Goa & 28.00 & Rajasthan & 21.7 \\
Gujrat & 20.1 & Sikkim & 37.4 \\
Haryana & 28.7 & Tamil Nadu & 48.6 \\
Himachal Pradesh & 37.9 & Telengana & 35.7 \\
J\&K & 27.7 & Tripura & 21.2 \\
Jharkhand & 18.00 & U.P & 25.9 \\
Karnataka & 27.8 & Uttrakhand & 36.3 \\
Kerla & 36.2 & West Bengal & 18.7 \\
\hline
\end{tabular}

Source: AISHE (2017-18).
Table 4: Enrollment in Government/ Private Higher Education Institutions

\begin{tabular}{lllll}
\hline Level & Courses & Government & $\begin{array}{l}\text { Private } \\
\text { Aided }\end{array}$ & Private \\
\hline UG & Academic & 47.9 & 21.6 & 30.5 \\
& Professional & 22.6 & 9.1 & 68.3 \\
\hline PG & Academic & 67.5 & 16.9 & 15.5 \\
& Professional & 38.9 & 7.2 & 53.9 \\
\hline
\end{tabular}

Source: AISHE (2017-18).

The total estimated student enrolment is 3,66,42,378 out of which nearly 52.4 percent are male and rest 47.6 percent are female students. Accessibility to higher education is measured in terms of gross enrolment ratio (GER) which is the ratio of persons enrolled in higher education institutions to total population of the persons in the age group of 1823 years. Gross Enrolment Ratio (GER) in Higher education in India is 25.8 percent for the year of 2017-18. GER for male population is 26.3 percent and for females, it is 25.4 percent. For Scheduled Castes, it is 21.8 percent and for Scheduled Tribes, it is 15.9 percent as compared to the national GER of 25.8 percent (AISHE 2017-18).

\section{Disparities in Accessing the Higher Education}

Though getting education is a right of every individual but the conditions prevailing in the society affects the life of every individual. The gradual withdrawal of the state from the higher education system and the active participation of the private players have led to the exclusion of marginalized groups from higher education. The high cost of education in these private educational institutions is the major concern to the access and quality in higher education. This leads to many disparities like regional, gender, caste and interstate disparities etc.

\section{(I) Disparities related to the expansion of higher education institutions and enrolment in these institutions}

The first thing related with the issue of disparities in higher education is the unequal growth of higher education institutions and enrolment in these institutions. As Table 1 and 2 shows the more growth in the private higher education institutions. The above discussion about the expansion of higher education also shows that the 65.2 percent 
institutions enrolled less than 500 students and only 3.6 percent colleges enrolled the students more than 5000. Another issue is the enrolment in undergraduate courses in government colleges is less than the post graduation in the government colleges as the students in this era of market based and more professional skills based jobs, attracted towards the more professional courses which are provided by the private institutions due to which more enrolment in under graduation courses is in private professional colleges (Table 4). And further in the post graduation courses there is less enrolment than the under graduation courses which also shows that the students drop out after UG courses and then it becomes more less in the research related courses like M.phil and Ph.D. The highest number of students is enrolled at Under Graduate level across India. Out of the total enrolment of 3,66,42,378 students, a vast majority of 2,90,16,350 students are enrolled in Under Graduate that constitute the 79.19 percent of the total. On the other hand, 11.23 percent students are enrolled in Post-Graduation which is approximately 41.14 lakh students. There are 3,110 students enrolled in Integrated Ph.D. in addition to 1,61,412 students enrolled at Ph.D. Level. The small share of 7.39 percent students enrolled at Diploma level in India that amounts to around 27.0 lakh students and out of this majority of students is enrolled in Teacher Training, Nursing and Technical streams. However, a small share of 1.77 lakh and 2.35 lakh students are enrolled each at Certificate and PG Diploma levels, respectively, constituting approximately 0.48 percent and 0.53 percent of the total share at each level (AISHE, 2018).

\section{(II) Access to higher education by social groups}

The privatization and commercialization of higher education has put serious threat for inclusion of various social groups who belongs to disadvantaged group. The accessibility to higher education by various groups in terms of caste and religion vary from the other groups or elite classes. The GER for Scheduled Castes is 21.8 percent and for Scheduled Tribes, it is 15.9 percent as compared to the national GER of 25.8 percent. SC student enrolment is 14.4 percent of the total enrolment and the male-female ratio is more or less similar to the All Category. On the other hand, students belonging to ST category constitute only 5.2 percent of the total student enrolment and male female ratio is similar to All Category. 35 percent of the total students belong to OBC with 52 percent of male OBC students. 5 percent students belong to Muslim Minority and 2.2 percent are from other Minority Communities. Muslim Minority has more male students than females where as other Minority has more females than males (AISHE 2017-18).

\section{(III) Inter-State variations}

In India there is inter-state variation in terms of number of higher education institutions and enrolment of students. According to All India Higher Education Survey Report (2017-18) the top 8 States in terms of highest number of colleges in India are Uttar Pradesh, Maharashtra, Karnataka, Rajasthan, Andhra Pradesh, Tamil Nadu, Gujarat and Madhya Pradesh. Andhra Pradesh and Telangana have about 82 percent Private-unaided colleges and Tamil Nadu has 76.2 percent Private unaided colleges, whereas, Assam has 12.0 percent and Chandigarh has only 8.0 percent Privateunaided colleges. Uttar Pradesh comes at number one with the highest student enrolment followed by Maharashtra and Tamil Nadu. Six States with highest student enrolment are Uttar Pradesh, Maharashtra, Tamil Nadu, Karnataka, West Bengal and Rajasthan constitute nearly 53.8 percent of the total student enrolment in India and rest of the 30 States (including UTs) have only 46.2 percent of the total student enrolment.

\section{(IV) Gender Disparities}

The access to higher education is also low for girls as compared to boys. The total GER in higher education in 2017-18 is 25.8 and the GER for males is 26.3 and for girls is 24.4 which clearly shows the gender disparity to access the higher education in India. These gender variations are also further widened among various states.

\section{CONCLUSION}

Despite huge expansion of higher education institutions and the growth in GER, there are many disparities prevalent among various sections of society. Even there is a huge difference among the higher education institutions like private and government institutions both in terms of their 
growing number and growth of GER in these institutions. Higher education is viewed as a long term social investment for the promotion of social and economic development of the individual as well as the country. The higher education sector in India growing at very fast rate and according to Martin Trow's (1973) classification of developmental stages of higher education system, it is moving towards the elite to massification of higher education. The transition from elite to mass higher education system within a span of just one decade and through the privatization route brings with it what Trow (1973) called a 'crisis'. It the limited expansion in terms of access to only elite and middle classes even with the disadvantaged it is the only middle class within them to access the higher education in this era of privatization. It leads to the exclusion of various social groups from higher education and then affects the inclusive development of the country. For the inclusive growth of the higher education system the state must take it into consideration that the uncontrolled private players are not only just expanding the higher education system only in terms of number of institutions but also neglects the issue of access, equity and quality of higher education. As we seen in our society, how many people after getting their graduation or post graduation degree got the employment? Though there is growth in the number of institutions and growth in the GER but the problem of unemployment is at its peak in our country. Now India has the youngest population in the world but the problem of unemployment is there which further questions our education system which does not provide the well educated and more skilled people to the country. So, there is urgent need to check the unequal expansion and the issues related with access, equity and quality of higher education.

\section{REFERENCES}

AISHE, 2018. Annual Report 2017-18. New Delhi: Ministry of Human Resource Development.

Kapur, D. and Mehta, P.B. 2004. Indian Higher Education Reform: From Half-Baked Socialism To Half-Baked Capitalism. CID Working Paper No.108, Harvard University: Center for International Development.

Kaur, S. 2014. "Policy Perspective for Expansion of Higher Education", Man and Development, 36(4): 31-38.

Patnaik, P. 2007. 'Alternative Perspective on Higher Education in the context of Globalization', Journal of Educational Planning $\mathcal{E}$ Administration, 21(4).

Rao, S.S. 2017. “Transition From Elite to Mass System of Higher Education-What does Massification mean for Equality?", Journal of Educational Planning and Administration, 31(2): 141-156.

Singh, R. 2014. The Politics of Neo-liberalism and Higher Education in India: Effects and Outcomes. Singh, K. \& Puar, S.S. (eds) Emerging Policy Regime in Indian Higher Education: Ensuing Issues and Concerns. Patiala: Twentyfirst Century Publications.

Tilak, J.B.G. 2014. "Private Higher Education in India", Economic and Political Weekly, 59(40): 32-38.

Tilak, J.B.G. 2018. Education and Development. New Delhi: Academic Foundation.

Trow, M. 1973. Problems in the Transition from Elite to Mass Higher Education, Berkeley, California: Carnegie Commission on Higher Education.

Varghese, N.V. 2015. Challenges of Massification of Higher Education in India, CPRHE Research Paper 1, New Delhi: NUEPA. 